\title{
Energy substrates for the rumen epithelium
}

\author{
BY DIDIER RÉMOND ${ }^{1}$, ISABELLE ORTIGUES ${ }^{2}$ AND \\ JEAN-PIERRE JOUANY ${ }^{1}$ \\ ${ }^{1}$ Station de Recherches sur la Nutrition des Herbivores et ${ }^{2}$ Laboratoire Croissance et Métabolismes \\ des Herbivores, INRA, Theix, 63122 St Genès-Champanelle, France
}

\section{Les substrats énergétiques utilisés par l'épithélium ruminal}

\begin{abstract}
RÉSUMÉ
A l'intérieur du rumen les aliments subissent une digestion microbienne très intense. Les acides gras volatils (AGV), produits terminaux de la fermentation des glucides alimentaires, sont largement absorbés à travers l'épithélium ruminal dont les besoins énergétiques, liés en grande partie au renouvellement cellulaire et aux processus de transports membranaires, peuvent ainsi être couverts soit par les substrats énergétiques apportés par le sang artériel (glucose, glutamine, etc.), soit par les AGV directement issus de la lumière ruminale. Avant le sevrage, les fermentations microbiennes à l'intérieur du rumen ne sont pas encore bien établies et le glucose constitue une source d'énergie importante pour l'épithélium. Ensuite son utilisation diminue au profit des AGV qui deviennent les principaux substrats énergétiques captés par la paroi du rumen. Contrairement à l'intestin grêle, l'épithélium ruminal utilise peu la glutamine comme substrat énergétique. Une partie des AGV absorbés est métabolisée dans l'épithélium ruminal et $18-33 \%$ de l'acide acétique, $30-70 \%$ de l'acide propionique et $74-90 \%$ de racide butyrique produits dans le rumen n'apparaissent pas dans la circulation sanguine. Ce métabolisme dépend en premier lieu d'une étape d'activation transformant les AGV en acyl-CoA. L'activité relative des acyl-CoA vis-à-vis de l'acide acétique, de l'acide propionique et de l'acide butyrique, mesurée in vitro, est en accord avec les différences de taux de métabolisme observées in vivo entre les différents AGV. Ces différences de capacité d'activation ainsi que les compétitions entre AGV au niveau de l'étape d'activation semblent favoriser le métabolisme de l'acide butyrique au niveau de l'épithélium ruminal alors que l'acide propionique serait principalement métabolisé dans le foie et l'acide acétique dans les tissus périphériques. La production d'énergie par oxydation complète des AGV n'est cependant pas l'unique voie du métabolisme des différents $\mathrm{AGV}$. L'acide butyrique est relativement peu oxydé dans l'épithélium et la principale orientation de son métabolisme est la production de composés cétoniques. Le métabolisme de l'acide propionique peut libérer de l'énergie et du $\mathrm{CO}_{2}$ mais il peut également donner du lactate, du pyruvate ou de l'alanine; l'importance relative de chacune de ces voies métaboliques n'est pas encore bien connue. L'acide acétique peut servir de précurseur à la synthèse de composés cétoniques mais sa principale utilisation est la production d'énergie via le cycle de Krebs. Ainsi, bien que le taux de métabolisme de l'acide acétique dans l'épithélium soit faible, étant donné que cet AGV est le plus abondamment produit dans le rumen, il constitue vraisemblablement la principale source d'énergie pour les cellules épithéliales.
\end{abstract}


The ruminant digestive tract is distinctive in that it has a compartmentalized stomach. In the rumen, which is the first and the largest compartment, ingesta undergo extensive microbial digestion, and carbohydrate fermentation produces large amounts of acetate, propionate and butyrate. These three acids are generally referred to as volatile fatty acids (VFA). The molar ratios for acetate:propionate:butyrate vary from 70:20:10 with a hay diet to 50:35:15 with a concentrate diet. The VFA produced in the rumen constitute the most important energy source for the ruminants; they account for $50-75 \%$ of the total metabolizable energy of the feed (Siciliano-Jones \& Murphy, 1989). Although the rumen is lined by a keratinized epithelium, VFA are easily absorbed across the rumen wall, and this absorption accounts for $65-85 \%$ of the rumen production of VFA, the remainder flow out of the rumen and are absorbed farther down the tract (Weston \& Hogan, 1968; Peters et al. 1990, 1992). Thus, in addition to the energy substrates available in the arterial supply, such as glucose, glutamine and free fatty acids, the rumen epithelium may use the VFA absorbed directly as an energy source.

The energy expenditure of the ruminant stomach accounts for about $49 \%$ of that of the whole portal-drained viscera (Reynolds \& Huntington, 1988a), which account for 16-29\% of the whole-body expenditure (Ortigues, 1991). The two major biochemical events responsible for this energy use in the rumen epithelium are $\mathrm{Na}^{+}, \mathrm{K}^{+}$-ATPase $(E C$ 3.6.1.37) activity and protein synthetic activity, each of which constitute one-fifth of the rumen epithelium $\mathrm{O}_{2}$ consumption (Kelly et al. 1993).

The proliferation of the rumen epithelium at high intakes of easily-fermentable carbohydrates is well documented (Gaebel et al. 1987). When the diet is changed from roughage to concentrate the mitotic index increases rapidly in the epithelium (Goodlad, 1981). Thus, according to the diet the energy demand of the epithelium for new protein synthesis may be greatly affected.

The objective of the present paper is to review the current knowledge of the energy substrates taken up by the rumen epithelial cells, the biochemical pathways involved in their metabolism, and the factors determining the extent of their use in the energy ntetabolism of the rumen epithelium.

\section{ENERGY SUBSTRATE UPTAKE BY THE RUMEN WALL IN VIVO}

Recent advances in the implantation of chronic catheters and in blood-flow measurement techniques (Huntington et al. 1989; Rémond et al. 1993b) have allowed in vivo assessments of the net uptake of arterial metabolites and absorbed VFA across the stomach wall. The net use of arterial glucose by the whole stomach and by the rumen wall itself has been observed in ruminants on different diets (Reynolds \& Huntington, 1988a; Rémond et al. 1993a). There have been reports also on the net uptake of arterial glutamine and glutamate (Broad et al. 1980; Reynolds \& Huntington, 1988a). Although the rumen wall is divisible into similar weights of muscle and epithelium, $85-97 \%$ of the blood flow goes to the epithelium (Engelhardt \& Hales, 1977; Barnes et al. 1983) and, thus, virtually all the glucose and glutamine extracted by the rumen wall is available to the epithelium. From the rumen production rates and portal fluxes of VFA it has been estimated that $18-30 \%$ of the acetate, $30-70 \%$ of the propionate and $74-90 \%$ of the butyrate produced are metabolized by the stomach wall during their absorption (Table 1). 
Table 1. Published results on the extent of volatile fatty acid (VFA) metabolism by the ruminant stomach wall

\begin{tabular}{|c|c|c|c|c|}
\hline \multirow[b]{2}{*}{ Animals } & \multicolumn{3}{|c|}{ VFA* } & \multirow[b]{2}{*}{ References } \\
\hline & Acetate & Propionate & Butyrate & \\
\hline Sheep & 30 & 50 & 90 & Bergman \& Wolf (1971) \\
\hline Sheep & - & 40 & - & Weekes \& Webster (1975) \\
\hline Sheep & 30 & - & - & Pethick et al. (1981) \\
\hline Cattle & 30 & - & - & Huntington et al. (1983) \\
\hline Cattle & - & 70 & - & Seal et al. (1989) \\
\hline Sheep & 33 & 30 & 78 & Gross et al. (1990) \\
\hline Cattle & - & - & 74 & Krehbiel et al. (1992) \\
\hline Cattle & 18 & 54 & - & Seal \& Parker (1994) \\
\hline
\end{tabular}

* VFA metabolized in stomach epithelium given as a percentage of rumen production.

From the net stomach flux of VFA reported by Reynolds \& Huntington $(1988 b)$ in steers on a lucerne (Medicago sativa) diet, or from net rumen fluxes reported by Rémond et al. (1993a) in sheep fed on orchard-grass (Dactylis glomerata) hay, and assuming a metabolism in the stomach wall of $30 \%$ for acetate, $50 \%$ for propionate and $90 \%$ for butyrate (estimations of Bergman \& Wolff (1971) for sheep on a lucerne diet), it may be estimated that, on an energy basis (calculated from heats of combustion of acetate, propionate, butyrate and glucose), net glucose uptake is only equivalent to about $3 \%$ of the energy absorbed daily in the form of VFA by the rumen wall. Net glutamine uptake seems to be 100 -fold lower than net glucose uptake (Broad et al. 1980; Reynolds \& Huntington, 1988a), which suggests that glutamine is not an important energy source for the stomach epithelium, as it is in small intestinal tissues (Britton \& Krehbiel, 1993). Complete oxidation of the VFA metabolized by the stomach wall would, thus, provide considerable energy, far greater than that of glucose and glutamine. However, oxidative metabolism is not the only pathway of VFA metabolism, and the rumen epithelium is known to produce large amounts of ketone bodies from VFA.

Pethick et al. (1981) estimated that about $75 \%$ of the acetate used in portal-drained tissues is oxidized directly to $\mathrm{CO}_{2}$ and in vitro studies have shown that acetate in the rumen epithelium is a poor precursor for ketogenesis (Goosen, 1976). No direct assessment of the extent of the metabolism of acetate to $\mathrm{CO}_{2}$ or to ketone bodies in the rumen epithelium, in vivo, is available.

Butyrate is the major precursor for ketogenesis in rumen tissues. From data of Krehbiel et al. (1992) it may be calculated that, for the steers that did not receive butyrate infusion, butyrate metabolism by the stomach wall accounted for $72 \%$ of the rumen production $(109 \mathrm{mmol} / \mathrm{h})$ and that $83 \%$ of the metabolized butyrate was converted to ketone bodies (assuming that portal ketones were mainly derived from butyrate). During short-term variations, butyrate conversion to ketone bodies does not linearly increase with butyrate absorption rate, suggesting that the biochemical pathways for ketogenesis become saturated with high rates of absorption (Krehbiel et al. 1992; Rémond et al. 1993a). Although the production of ketone bodies, in particular of $D(-)-\beta$-hydroxybutyrate ( $D \beta H O B$ ), is the main pathway of butyrate metabolism in the stomach epithelium, complete oxidation of butyrate cannot be ruled out as a source of 
energy for the epithelium because butyrate is the most extensively metabolized VFA in the epithelium and because its energy value is higher than that of propionate and acetate.

In vitro studies have shown that the use of propionate by the rumen epithelium, unlike that of butyrate or acetate, does not lead to the formation of ketone bodies (Weigand et al. 1975), and lactate and $\mathrm{CO}_{2}$, with small amounts of pyruvate, are the major endproducts of propionate metabolism (Harmon et al. 1991). There is disagreement about the quantitative significance of these metabolic pathways of propionate in vivo. The study of Leng et al. (1967) indicated that there was extensive conversion of propionate into lactate in the rumen epithelium of sheep, whereas the results of Weekes \& Webster (1975) showed that the ability of the rumen epithelium to form lactate from propionate was limited and that most of the lactate formed in the portal-drained viscera was probably derived from glucose. Furthermore, Weigand et al. (1972) claimed that only $2 \cdot 3 \%$ of the propionate absorbed across the portal-drained viscera of calves was converted into lactate. Species differences probably also exist in the quantitative importance of lactate production from propionate (Elliot, 1980). Consequently, lactate does not appear to be the major endproduct of propionate metabolism and oxidation to $\mathrm{CO}_{2}$ may be an important pathway of propionate metabolism, but conversion to other products, such as alanine, is also conceivable (Bergman, 1990).

In conclusion, in vivo measurements of VFA metabolism in the rumen wall are scarce, and the quantitative significance of the metabolic pathways involved in VFA transformation is not fully understood. Acetate production in the rumen is usually high, and although acetate metabolism in the epithelium is proportionally low, complete oxidation of acetate is probably the greatest energy source for rumen epithelial cells. Britton \& Krehbiel (1993) even calculated that acetate metabolism in the stomach tissues could account for all the energy used in these tissues.

\section{ENZYMIC ACTIVITY AND ENERGY SUBSTRATES INTERACTION}

\section{VFA activation}

The initial metabolic step of VFA metabolism involves the formation of CoA esters of acetate, propionate and butyrate. The existence of short-chain acyl-CoA synthetases in the rumen epithelium has been widely documented. Their activities appear to be evenly distributed between the cytoplasm and the mitochondria (Ash \& Baird, 1973). The relative activities of acyl-CoA synthetases for acetate, propionate and butyrate activation observed in vitro (Ash \& Baird, 1973; Harmon et al. 1991), are consistent with the extent of the metabolism of these three VFA in the rumen epithelium in vivo. Several acyl-CoA synthetases exist in animal tissues, each with its own substrate specificities and kinetic characteristics. Ash \& Baird (1973) suggested that these properties may be a key regulatory factor in VFA epithelial metabolism.

Competition exists in the activation of a specific VFA into its respective acyl-CoA when incubated in vitro with other VFA. Acetate activation is depressed by the presence of butyrate and to a lesser extent by that of propionate. Propionate activation is severely inhibited by the presence of butyrate but not affected by acetate, and butyrate activation is not greatly modified by the presence of either acetate or propionate (Ash \& Baird, 1973; Scaife \& Tichivangana, 1980; Harmon et al. 1991). Relative capacities for VFA activation in the epithelium and competition between VFA at this activation step in the 
epithelium seems to ensure that butyrate is metabolized mainly in the rumen epithelium, whereas propionate is metabolized by the liver and acetate by peripheral tissues and other organs of the portal-drained viscera (Ash \& Baird, 1973; Bergman, 1990). This autoregulation in the rumen epithelium could be linked to the existence of two short-chain acyl-CoA synthetases, one being non-specific for the three VFA, and one accepting only butyrate as substrate (Scaife \& Tichivangana, 1980).

Although in vitro studies suggest that acyl-CoA synthetases have a regulatory role in VFA metabolism, Britton \& Krehbiel (1993) stress that, as long as Michaelis constants, inhibition constants and tissue concentrations of substrates and inhibitors involved in the reactions are not known, this regulatory role will remain speculative. Furthermore, Krehbiel et al. (1992) observed no significant changes in propionate metabolism in the rumen epithelium of steers showing increasing levels of butyrate absorption, and the significance of propionyl-CoA inhibition by butyrate in determining the extent of propionate metabolism, in vivo, is thus questionable.

The production of CoA esters of VFA by transacylation with acetoacyl-CoA could be another pathway for VFA activation, as suggested by Emmanuel \& Milligan (1983), who detected CoA transferases in the epithelium. The transacylation activities for acetate, propionate and butyrate are consistent also with the respective rates of metabolism of these VFA in vivo. The relative importance of these two kinds of activation is not known, but transacylation could be a means for the epithelium to spare energy because unlike the acyl-CoA synthetase-mediated reaction, transacylation does not require ATP (Emmanuel \& Milligan, 1983).

\section{Biochemical pathways}

After activation, the orientation of the metabolism will determine the amount of energy produced from each VFA in the epithelium. The known biochemical pathways for acetate, propionate and butyrate metabolism in the rumen epithelium are shown in Figs. 1 and 2 . Acetate and butyrate may be completely oxidized to $\mathrm{CO}_{2}$ entering the Krebs cycle via acetyl-CoA production. A unique aspect of rumen epithelium is the importance of ketone-body production, as already mentioned. Acetoacetyl-CoA, which is an intermediary in butyrate oxidation, may be a substrate for ketogenesis. Three biochemical pathways for acetoacetate $(\mathrm{AcAc})$ production from acetoacetyl-CoA have been identified by Bush \& Milligan (1971): acyl transfer with succinate, direct deacylation and the 3-hydroxymethylglutaryl-CoA pathway, the relative proportions of these pathways being 70:16:14 respectively. Furthermore, transacylation between acetoacetyl-CoA and butyrate or acetate could also play a significant role in AcAc production (Emmanuel \& Milligan, 1983). The reduction of $\mathrm{AcAc}$ by $\mathrm{D} \beta \mathrm{HOB}$ dehydrogenase $(E C$ 1.1.1.30) produces $\mathrm{D} \beta \mathrm{HOB}$ which is the most abundant ketone body released in portal blood. Hydroxybutyrate may also be derived by an alternative mechanism from intermediaries in the transformation of butyryl-CoA to acetoacetyl-CoA (Emmanuel et al. 1982). In vitro, the production rate of $D \beta H O B$ from this alternative route is 0.60 times the rate by the AcAc route, and it may contribute significantly to ketogenesis in vivo (Emmanuel et al. 1982). Acetate metabolism may also result in ketone-body production via acetoacetyl-CoA. The equilibrium between acetoacetyl-CoA and acetyl-CoA and the regulation of the enzymes involved may play a considerable role in the orientation of acetate and butyrate metabolism. A low rate of interconversion between acetyl-CoA and 


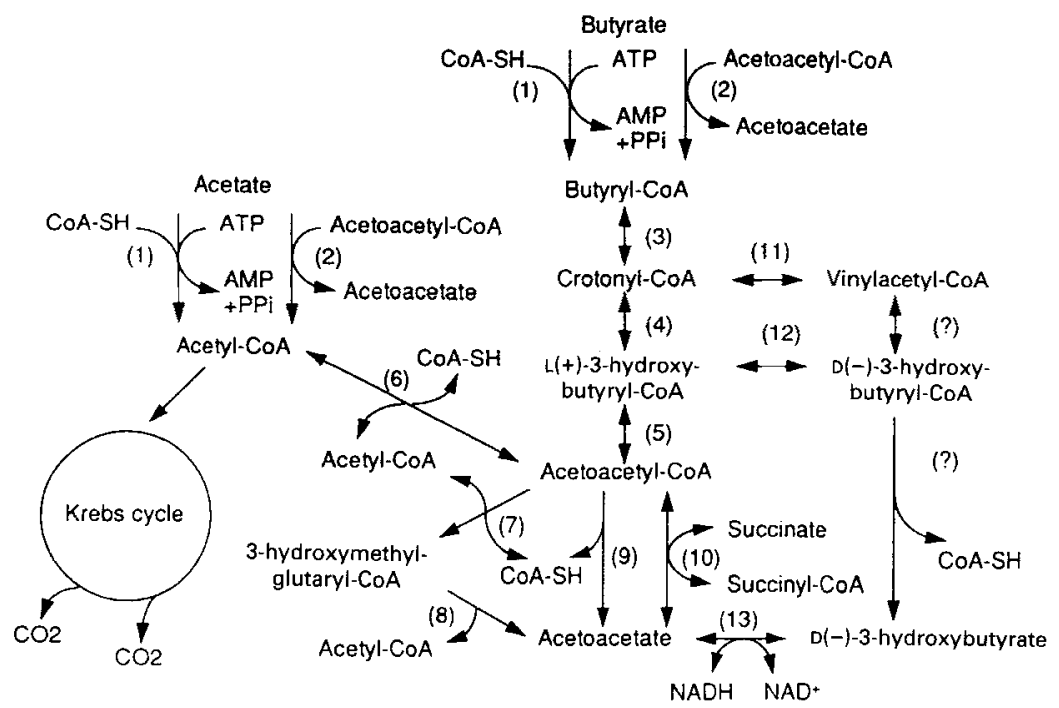

Fig. 1. Metabolic routes of acetate and butyrate transformation in rumen epithelium. (1), Acyl-CoA synthetase (EC 6.2.1.); (2), acyl: acetoacetyl-CoA transferase; (3), acetyl-CoA thiolase (EC 2.3.1.9); (4), butyryl-CoA dehydrogenase (EC 1.3.99.2); (5), crotonase (EC 4.2.1.17); (6), L(+)-3-hydroxybutyryl-CoA dehydrogenase (EC 1.1.1.35); (7), 3-hydroxy-3-methylglutaryl-CoA synthetase ( $E C 4.1 .3 .5)$; (8), 3-hydroxy-3-methylglutarylCoA lyase (EC 4.1.3.4); (9), deacylase (EC 3.1.2.11); (10), 3-oxo acid-CoA transferase (EC 4.1.3.4); (11), vinylacetyl-CoA isomerase (EC 5.3.3.3); (12), 3-hydroxybutyryl-CoA racemase $(E C 5.1 .2 .3)$; (13), D(-)-3hydroxybutyrate dehydrogenase (EC 1.1.1.30). PPi, pyrophosphate.

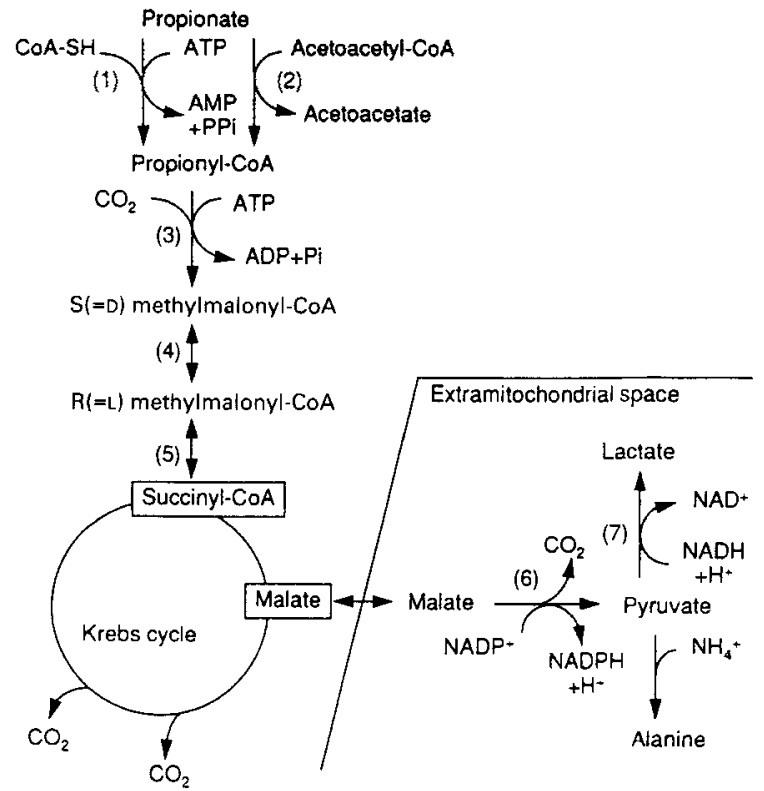

Fig. 2. Major metabolic routes of propionate transformation in the rumen epithelium. (1), Acyl-CoA synthetase (EC 6.2.1.-); (2), propionate: acetoacetyl-CoA transferase; (3), propionyl-CoA carboxylase $(E C$ 6.4.1.3); (4), methylmalonyl-CoA racemase; (5), methylmalonyl-CoA mutase; (6), malic enzyme (EC 1.1.1.40); (7), lactate dehydrogenase (EC 1.1.1.27). PPi, pyrophosphate. 
acetoacetyl-CoA would explain why acetate is preferably oxidized to $\mathrm{CO}_{2}$ whereas butyrate metabolism gives rise essentially to ketone bodies.

Ketogenesis in the rumen may be regulated by certain metabolites. Beck et al. (1984) have shown that increasing the butyrate concentration in the incubation medium produces a decrease in the proportion of butyrate oxidized to $\mathrm{CO}_{2}$ and an increase in the proportion of ketone-body production. The presence of glucose significantly increases ketogenesis from butyrate and decreases its oxidation to $\mathrm{CO}_{2}$, whereas $\mathrm{NH}_{4}^{+}$and pyruvate have the opposite effect (Stangassinger et al. 1979; Beck et al. 1984; Giesecke et al. 1985). Giesecke et al. (1985) suggested that any metabolite producing an increase in NADH:NAD ${ }^{+}$in the epithelium may stimulate ketogenesis and spare butyrate from oxidation. The effects of propionate and acetate on ketone-body production are less clear. The addition of propionate to the incubation medium does not have an anti-ketogenic effect in the rumen epithelium as it does in the liver (Bush et al. 1970). Baldwin \& Jesse (1991) even reported an increase in $\mathrm{D} \beta \mathrm{HOB}$ production from butyrate when propionate was added to the incubation medium of isolated cells. Acetate seems to have the opposite effect and when the rumen epithelium is incubated with the three VFA, D $B H O B$ production from butyrate seems to be the outcome of the antagonist effect of propionate and acetate (Baldwin \& Jesse, 1991). In vivo, with an increasing level of propionate absorption, $\mathrm{D} \beta \mathrm{HOB}$ production by the non-mesenteric tissues decreases while the extent of butyrate metabolism does not appear to be affected (Seal \& Parker, 1994), suggesting an anti-ketogenic effect of propionate in vivo.

The orientation of propionate metabolism in the rumen epithelium is less documented. After carboxylation, propionate may enter the Krebs cycle, via succinyl-CoA, to be totally oxidized to $\mathrm{CO}_{2}$ or to produce pyruvate, lactate or alanine, from malate or oxaloacetate (Fig. 2). The high activity of malic enzyme ( $E C$ 1.1.1.40), compared with phosphoenolpyruvate carboxykinase (EC 4.1.1.32), and the high activity of lactate dehydrogenase (EC 1.1.1.27; Young et al. 1969; Weekes, 1974; Bush, 1982) indicate that lactate production from malate decarboxylation may be a predominant pathway for propionate metabolism. Weekes (1974) reported that lactate and pyruvate formation from propionate, in vitro, is relatively insensitive to the presence of other VFA. Furthermore, the presence of glucose together with propionate results in a synergistic increase in lactate and pyruvate whereas $\mathrm{NH}_{3}$ has an inhibitory effect on lactate formation (Weekes, 1974). Although the metabolic pathway for the production of lactate from propionate is undoubtedly present in the rumen epithelium, the question of how extensively propionate is oxidized or converted to lactate or other products during absorption remains unresolved.

Glucose uptake by the rumen epithelium, in vivo, is low compared with that of VFA; its oxidation, however, may produce significant amounts of energy. Glucose uptake by epithelial tissues in vitro is depressed by the VFA, which suggests that their presence restricts the utilization of glucose by the rumen epithelium (Harmon, 1986). Inversely, glucose may enhance the production of ketone bodies from butyrate and the production of lactate from propionate and, therefore, limit the complete oxidation of these VFA by the rumen epithelium in vitro. Glutamine uptake by epithelial tissues in vitro is low and only a small percentage of glutamine is converted to $\mathrm{CO}_{2}$ (Harmon, 1986), which confirms in vivo observations suggesting that glutamine is not an important energy substrate for the rumen epithelium. 


\section{ENERGY SUBSTRATE UTILIZATION ACCORDING TO PHYSIOLOGICAL STATE AND DIET}

At birth the rumen is a non-functional sac accounting for about $30 \%$ of the empty stomach mass; in mature ruminants it accounts for about $70 \%$. This development of the rumen is rapid and essentially complete by 8 weeks of age (Lyford, 1988). Growth of the rumen is stimulated by the initiation of solid-food intake and the concomitant establishment of rumen fermentations. Metabolic adaptations occur in the epithelium throughout this developmental period. In the preruminant the primary energy substrate available for the epithelium is blood glucose, while thereafter large amounts of lactate and VFA produced by rumen fermentation become available. After a short postnatal development period of about 2 weeks, the rumen epithelium is able to oxidize glucose, lactate and butyrate at high rates (Giesecke et al. 1979; Baldwin \& Jesse, 1992). By the time of weaning, at about 8 weeks of age, the capacity for glucose uptake by the rumen epithelium diminishes (Giesecke et al. 1979), epithelial cells seem to lose their ability to oxidize glucose at high rates and other substrates such as VFA may become the primary oxidative energy source: by 8 weeks of age butyrate oxidation rate is 10 -fold higher than glucose oxidation rate (Baldwin \& Jesse, 1992). After the postnatal development period, the ability of the epithelium to oxidize butyrate is independent of epithelial growth (Giesecke et al. 1979; Baldwin \& Jesse, 1992), whereas the capacity of rumen cells to produce ketone bodies from VFA, which is very low before weaning, rapidly increases thereafter (Giesecke et al. 1979; Baldwin \& Jesse, 1992). The metabolic maturation of rumen epithelium thus occurs with the functional development of the rumen. Before weaning, during the rapid growth phase of the rumen, glucose is an important energy substrate for the epithelium. By the time of weaning, with the appearance of large amounts of VFA in the rumen, the role of glucose as an energy substrate declines. Simultaneously the ketogenic capacity of rumen cells increases, which probably limits the use of butyrate in the Krebs cycle and favours the use of other substrates, such as acetate or propionate, for energy production.

In mature ruminants, dietary changes affect the mass of the mucosa as well as the type and extent of papillation (Fell \& Weekes, 1975; Weigand et al. 1975). These morphological changes of the rumen epithelium, induced by both the level of intake and the composition of the diet, occur simultaneously with metabolic adaptation in epithelial cells. Harmon et al. (1991) reported that greater intake, associated with a higher level of VFA in the rumen, slightly increased acetyl-, propionyl-, and butyryl-CoA synthetases in the epithelium. This rise in the capacity of VFA activation was accompanied by an increase in ketogenesis from acetate and butyrate, and an increase in lactate and pyruvate formation from propionate, whereas the oxidation rates of the three VFA (per unit tissue weight) were not affected. Therefore, with an increased level of intake the epithelium seems to adapt its metabolism to increase the conversion rate of the absorbed VFA and to limit the release of intact VFA into the bloodstream. When there is a change from a roughage to a concentrate diet, the molar proportions of ruminally-produced propionate or butyrate generally increase with respect to that of acetate. Butyrate, and to a lesser extent propionate, are known to be potent trophic factors for the rumen epithelium. The increase in acetate, propionate and butyrate oxidation rate (Harmon et al. 1991) and in glucose oxidation rates (Harmon, 1986) observed with a grain diet may provide additional energy to cover the energy cost of the increase in epithelial cell proliferation. Furthermore, the increase in metabolism of propionate to pyruvate 
observed by Harmon et al. (1991) may generate extramitochondrial NADPH required for biosynthetic processes associated with cell turnover (Weekes, 1972).

During fasting, when rumen VFA availability decreases, the rumen epithelium of mature ruminants is able to oxidize long-chain fatty acids, such as palmitate, for energy production (Jesse et al. 1992). Glucose oxidation in isolated epithelial cells is largely depressed by palmitate addition (Jesse et al. 1992). Thus, in the absence of sufficient amounts of VFA, the epithelium seems to prefer blood long-chain fatty acids rather than glucose as the energy substrate. In fed ruminants, the oxidation of long-chain fatty acids is limited because of the inhibitory effect of ruminally-derived metabolites such as butyrate and $\mathrm{NH}_{3}$ (Jesse et al. 1992).

\section{CONCLUSION}

VFA from rumen fermentations constitute the primary energy source for the ruminant animal. Most are absorbed across the rumen wall, and the rumen epithelium uses part of them to meet its energy needs. The percentage of acetate metabolized in the epithelium is low, but the amount of acetate absorbed is higher than that of the other VFA. As its metabolism is directed mainly towards a complete oxidation, acetate could be the primary energy substrate for the epithelium. Propionate metabolism in the epithelium is high, but the orientation of this metabolism remains to be elucidated. The transformation of propionate to lactate may generate NADPH required for synthetic processes in the epithelium, and propionate may also be used as a source of $\mathrm{C}$ skeleton for new cell synthesis, but the extent of its use as an energy substrate in the epithelium is not fully understood. Butyrate is the most abundantly metabolized VFA in the rumen epithelium and ketogenesis is the most important direction of its metabolism. This transformation could be a way of detoxifying this acid and generating substrates particularly suited to by-pass the liver and provide energy for extrahepatic tissues. Blood glucose is an important energy substrate for the rumen epithelium during the preweaning period, thereafter its use declines. In mature ruminants, when VFA production is insufficient, long-chain fatty acids seem to be the substrates preferred for energy production. Absorption of VFA across the rumen epithelium plays a key role in energy supply to the animal. The extent of the use and transformation of these energy substrates by the epithelium will have important consequences on the availability of nutrients required for ruminant growth and production processes. A better understanding of VFA metabolism in the rumen epithelium may make it possible to determine how to manipulate the diet to spare their use in the epithelium and to increase the supply of key metabolites to productive tissues.

\section{REFERENCES}

Ash, R. \& Baird, G. D. (1973). Activation of volatile fatty acids in bovine liver and rumen epithelium. Biochemical Journal 136, 311-319.

Baldwin, R. L. \& Jesse, B. W. (1991). Technical note: isolation and characterization of sheep ruminal epithelial cells. Journal of Animal Science 69, 3603-3609.

Baldwin, R. L. \& Jesse, B. W. (1992). Developmental changes in glucose and butyrate metabolism by isolated sheep ruminal cells. Journal of Nutrition 122, 1149-1153.

Barnes, R. J., Comline, R. S. \& Dobson, A. (1983). Changes in the blood flow to the digestive organs of sheep induced by feeding. Quarterly Journal of Experimental Physiology 68, 77-88. 
Beck, U., Emmanuel, B. \& Giesecke, D. (1984). The ketonic effect of glucose in the rumen epithelium of ovine (Ovis aries) and bovine (Bos taurus) origin. Comparative Biochemistry and Physiology 77, 517-521.

Bergman, E. N. (1990). Energy contributions of volatile fatty acids from the gastrointestinal tract in various species. Physiological Reviews 70, 567-590.

Bergman, E. N. \& Wolff, J. E. (1971). Metabolism of volatile fatty acids by liver and portal-drained viscera in sheep. American Journal of Physiology 221, 586-592.

Britton, R. \& Krehbiel, C. (1993). Nutrient metabolism by gut tissues. Journal of Dairy Science 76, $2125-2131$.

Broad, T. E., Milligan, L. P. \& Boland, M. J. (1980). Arteriovenous changes in the concentration of glutamine and other metabolites across the rumen of sheep. Canadian Journal of Animal Science 60, 59-64.

Bush, R. S. (1982). Extraction of enzymes and assessments of metabolism in bovine rumen epithelium. Canadian Journal of Animal Science 62, 429-438.

Bush, R. S. \& Milligan, L. P. (1971). Enzymes of ketogenesis in bovine rumen epithelium. Canadian Journal of Animal Science 51, 129-133.

Bush, R. S., Milligan, L. P. \& Krishnamurti, C. R. (1970). Effects of propionate on ketogenesis from butyrate by bovine tissues. Canadian Journal of Animal Science 50, 210.

Elliot, J. M. (1980). Propionate metabolism and vitamin $\mathrm{B}_{12}$. In Digestive Physiology and Metabolism in Ruminants, pp, 485-503 [Y. Ruckebusch and P. Thivend, editors]. Lancaster: MTP Press Ltd.

Emmanuel, B. \& Milligan, L. P. (1983). Butyrate: acetoacetyl-CoA transferase activity in bovine rumen epithelium. Canadian Journal of Animal Science 63, 355-360.

Ernmanuel, B., Stangassinger, M. \& Giesecke, D. (1982). Production of D(-)-3-hydroxybutyrate by an alternate mechanism in the rumen epithelium of ovine (Ovis aries), and bovine (Bos taurus). Comparative Biochemistry and Physiology 72, 415-419.

Engelhardt, W. v. \& Hales, J. R. S. (1977). Partition of capillary blood flow in rumen, reticulum, and omasum of sheep. American Journal of Physiology 232, E53-E56.

Fell, B. F. \& Weekes, T. E. C. (1975). Food intake as a mediator of adaptation in the ruminal epithelium. In Digestion and Metabolism in the Ruminant, pp. 101-118 [I. W. McDonald and A. C. I. Warner, editors]. Armidale, NSW: University of New England Publishing Unit.

Gaebel, G., Martens, H., Suendermann, M. \& Galfi, P. (1987). The effect of diet, intraruminal pH and osmolarity on sodium, chloride and magnesium absorption from the temporarily isolated and washed reticulo-rumen of sheep. Quarterly Journal of Experimental Physiology 72, 501-511.

Giesecke, D., Beck, U. \& Emmanuel, B. (1985). Ketonic regulation by certain metabolites in the rumen epithelium. Comparative Biochemistry and Physiology 81, 863-867.

Giesecke, D., Beck, U., Wiesmayr, S. \& Stangassinger, M. (1979). The effect of rumen epithelial development on metabolic activities and ketogenesis by the tissue in vitro. Comparative Biochemistry and Physiology 62, $459-463$

Goodlad, R. A. (1981). Some effects of diet on the mitotic index and the cell cycle of the ruminal epithelium of sheep. Quarterly Journal of Experimental Physiology 66, 487-499.

Goosen, P. C. M. (1976). Metabolism in rumen epithelium. Oxidation of substrates and formation of ketone bodies by pieces of rumen epithelium. Zeitschrift für Tierphysiologie, Tierernährung und Futtermittelkunde 37, 14-25.

Gross, K. L., Harmon, D. L. \& Avery, T. B. (1990). Portal-drained visceral flux of nutrients in lambs fed alfalfa or maintained by total intragastric infusion. Journal of Animal Science 68, 214-221.

Harmon, D. L. (1986). Influence of dietary energy intake and substrate addition on the in vitro metabolism of glucose and glutamine in rumen epithelial tissue. Comparative Biochemistry and Physiology 85, 643-647.

Harmon, D. L., Gross, K. L., Krehbiel, C. R., Kreikemeier, K. K., Bauer, M. L. \& Britton, R. A. (1991). Influence of dietary forage and energy intake on metabolism and acyl-CoA synthetase activity in bovine ruminal epithelial tissue. Journal of Animal Science 69, 4117-4127.

Huntington, G. B., Reynolds, C. K. \& Stroud, B. H. (1989). Techniques for measuring blood flow in splanchnic tissues of cattle. Journal of Dairy Science 72, 1583-1595.

Huntington, G. B., Reynolds, P. J. \& Tyrrel, H. F. (1983). Net absorption and ruminal concentrations of metabolites in nonpregnant dry holstein cows before and after intraruminal acetic acid infusion. Journal of Dairy Science 66, 1901-1908.

Jesse, B. W., Solomon, R. K. \& Baldwin, R. L. (1992). Palmitate metabolism by isolated sheep rumen epithelial cells. Journal of Animal Science 70, 2235-2242.

Kelly, J. M., McBride, B. W. \& Milligan, L. P. (1993). In vitro Ouabain-sensitive respiration and protein synthesis in ruminal epithelial papillae of Hereford steers fed either alfalfa or bromegrass hay once daily. Journal of Animal Science 71, 2799-2808. 
Krehbiel, C. R., Harmon, D. L. \& Schnieder, J. E. (1992). Effect of increasing ruminal butyrate on portal and hepatic nutrient flux in steers. Journal of Animal Science 70, 904-914.

Leng, R. A., Steel, J. W. \& Luick, J. R. (1967). Contribution of propionate to glucose synthesis in sheep. Biochemical Journal 103, 785-790.

Lyford, S. J. Jr (1988). Growth and development of the ruminant digestive system. In The Ruminant Animal. Digestive Physiology and Nutrition, pp. 44-63 [D. C. Church, editor]. Englewood Cliffs, New Jersey: Prentice Hall.

Ortigues, I. (1991). Adaptation du métabolisme énergétique des ruminants à la sous-alimentation. Quantification au niveau de l'animal entier et de tissus corporels (Adaptation of energy metabolism to undernutrition in ruminants. Quantification in whole animal and in individual tissues). Reproduction Nutrition Development 31, 593-616.

Peters, J. P., Shen, R. Y. W. \& Robinson, J. A. (1992). Disappearance of acetic acid from the bovine reticulorumen at basal and elevated concentrations of acetic acid. Journal of Animal Science 70, $1509-1517$.

Peters, J. P., Shen, R. Y. W., Robinson, J. A. \& Chester, S. T. (1990). Disappearance and passage of propionic acid from the rumen of beef steer. Journal of Animal Science 68, 3337-3349.

Pethick, D. W., Linsay, D. B., Barker, P. J. \& Northrop, A. J. (1981). Acetate supply and utilization by the tissues of sheep in vivo. British Journal of Nutrition 46, 97-110.

Rémond, D., Chaise, J. P., Delval, E. \& Poncet, C. (1993a). Net flux of metabolites across the rumen wall of sheep fed twice a day with orchardgrass hay. Journal of Animal Science 71, 2529-2538.

Rémond, D., Poncet, C. \& Lefaivre, J. (1993b). Technical note: Ruminal vein catheterization and continuous blood flow measurement in ruminal arteries of sheep. Journal of Animal Science 71, 1276-1280.

Reynolds, C. K. \& Huntington, G. B. (1988a). Partition of portal-drained visceral net flux in beef steers. 1. Blood flow and net flux of oxygen, glucose and nitrogenous compounds across stomach and post-stomach tissues. British Journal of Nutrition 60, 539-551.

Reynolds, C. K. \& Huntington, G. B. (1988b). Partition of portal-drained visceral net flux in beef steers. 2. Net flux of volatile fatty acids, D- $\beta$-hydroxybutyrate and L-lactate across stomach and post-stomach tissues. British Journal of Nutrition 60, 553-562.

Scaife, J. R. \& Tichivangana, J. Z. (1980), Short chain acyl-CoA synthetases in ovine rumen epithelium. Biochimica et Biophysica Acta 619, 445-450.

Seal, C. J. \& Parker, D. S. (1994). Effect of intraruminal propionic acid infusion on metabolism of mesentericand portal-drained viscera in growing steers fed a forage diet: volatile fatty acids, glucose, and lactate. Journal of Animal Science 72, 1325-1334.

Seal, C. J., Sarker, A. \& Parker, D. S. (1989). Rumen propionate production rate and absorption of fermentation end-products into the portal vein of forage and forage-concentrate fed cattle. Proceedings of the Nutrition Society 48, 143A.

Siciliano-Jones, J. \& Murphy, M. R. (1989). Production of volatile fatty acids in the rumen and cecum-colon of steers as affected by forage:concentrate and forage physical form. Journal of Dairy Science 72, 485-492.

Stangassinger, M., Beck, U. \& Emmanuel, B. (1979). Is glucose ketonic in the rumen epithelium? Annales de Recherches Vétérinaires 10, 413-416.

Weekes, T. E. C. (1972). Effects of pregnancy and lactation in sheep on the metabolism of propionate by the ruminal mucosa and on some enzymatic activities in the ruminal mucosa. Journal of Agricultural Science, Cambridge 79, 409-421.

Weekes, T. E. C. (1974). The in vitro metabolism of propionate and glucose by the rumen epithelium. Comparative Biochemistry and Physiology 49, 393-406.

Weekes, T. E. C. \& Webster, A. J. F. (1975). Metabolism of propionate in the tissues of the sheep gut. British Journal of Nutrition 33, 425-438.

Weigand, E., Young, J. W. \& McGilliard, A. D. (1972). Extent of propionate metbolism during absorption from the bovine ruminoreticulum. Biochemical Journal 126, 201-209.

Weigand, E., Young, J. W. \& McGilliard, A. D. (1975). Volatile fatty acid metabolism by rumen mucosa from cattle fed hay or grain. Journal of Dairy Science 58, 1294-1300.

Weston, R. H. \& Hogan, J. P. (1968). The digestion of pasture plants by sheep. I. Ruminal production of volatile fatty acids by sheep offered diets of ryegrass and forage oats. Australian Journal of Agricultural Research 19, 419-432.

Young, J. W., Thorp, S. L. \& De Lumen, H. Z. (1969). Activity of selected gluconeogenic and lipogenic enzymes in bovine rumen mucosa, liver and adipose tissue. Biochemical Journal 114, 83-88. 